\title{
Correlation of residual subjective cognitive and depressive symptoms with social functioning in patients with remitted major depressive disorder
}

\author{
Remisyonda major depresif bozukluk tanılı hastalarda rezidüel subjektif bilişsel ve \\ depresif belirtilerin sosyal işlevsellik ile ilişkisi
}

\author{
Ender Kaya ${ }^{1}$, Fatma Barlas ${ }^{2}$
}

\begin{abstract}
Aim: In Major Depressive Disorder (MDD) residual symptoms cause disability in the remission phase even if they are mild. This study investigated the correlation of residual depressive and subjective cognitive symptom with social functioning in remitted MDD patients.

Methods: In the study, 51 patients who had been diagnosed with MDD before, were followed regularly and had been in remission for at least 6 months, were included. The socio-demographic data form, Beck Depression Inventory, Perceived Deficits Questionnaire-Depression, and Social Adaptation Self-evaluation Scale were applied to all participants. In the statistical analysis; descriptive analyses, Pearson's Correlation Analysis and linear regression analysis were used.

Results: Residual depressive symptom severity $(\mathrm{r}=-0.357, \mathrm{p}<0.05)$ and residual subjective cognitive symptom severity $(\mathrm{r}=-0.356, \mathrm{p}<0.05)$ were negatively correlated with social functioning level. In the linear regression analysis, it was determined that residual depressive and subjective cognitive symptom scores were a predictor of social functioning $(\mathrm{p}<0.05)$.

Conclusion: In the study, it was determined that residual depressive and subjective cognitive symptoms encountered in MDD remission phase might affect social functioning negatively. Rapid and practical subjective cognitive tests can be preferred in identifying cognitive symptoms in MDD remission phase.
\end{abstract}

Keywords: Depression, remission, residual subjective cognitive symptoms, residual depressive symptoms, psychosocial functioning.

Öz

Amaç: Major Depresif Bozuklukta (MDB) remisyon döneminde rezidüel belirtiler hafif şiddette olsa bile yeti yitimine neden olurlar. Bu çalışmada remisyonda olan MDB hastalarında, rezidüel depresif ve subjektif bilişse belirtilerin sosyal işlevsellikle ilişkisi araştırılmıştır.

Yöntemler: Çalışmaya öncesinde MDB tanısı almış, düzenli takip edilen ve en az 6 ay süre ile remisyonda olan 51 hasta dahil edilmiştir. Tüm katılımcılara sosyodemografik veri formu, Beck Depresyon Ölçeği, Algılanan Bilişsel Kusur Anketi-Depresyon, Sosyal Uyum Kendini Değerlendirme Ölçeği uygulanmıştır. İstatiksel analizde tanımlayıcı analizler, Pearson Korelasyon Analizi ve lineer regresyon analizi kullanılmıştır.

Bulgular: Rezidüel depresif belirti $(r=-0,357, p<0,05)$ ve subjektif bilişsel belirti şiddeti $(r=-0,356, p<0,05)$ ile sosyal işlevsellik düzeyi arasında negatif korelasyon saptandi. Lineer regresyon analizi ile rezidüel depresif ve subjektif bilişsel belirti puanlarının sosyal işlevselliğin yordayıcıları olduğu tespit edildi $(\mathrm{p}<0,05)$.

Sonuç: Bu çalışmada MDB remisyon döneminde görülen rezidüel depresif ve subjektif bilişsel belirtilerin sosyal işlevselliği olumsuz etkileyebileceği tespit edilmiştir. MDB da remisyon döneminde bilişsel belirtilerin saptanmasında hızlı ve pratik kullanımı olan subjektif bilişsel testler tercih edilebilir.

Anahtar Kelimeler: Depresyon, remisyon, rezidüel subjektif bilişsel belirtiler, rezidüel depresif belirtiler, psikososyal işlevsellik.
${ }^{1}$ University of Health Sciences, Prof. Dr. Cemil Tascioglu City Hospital, Clinic of Psychiatry, Istanbul, Turkey.

${ }^{2}$ University of Health Sciences, Prof. Dr. Cemil Tascioglu City Hospital, Clinic of Psychiatry, Istanbul, Turkey.

iD

EK: 0000-0002-8767-3798

FB: 0000-0001-7893-5437

Ethics Committee Approval: This study was approved by Clinical Research Ethics Committee with an approval number of 20.10.2020, 397.

Etik Kurul Onayı: Bu çalışma Yerel Etik Kurul tarafindan 20.10.2020, 397 onay numarası ile onaylanmıştır

Conflict of Interest: No conflict of interest was declared by the authors.

Çıkar Çatışması: Yazarlar çıkar çatışması bildirmemiștir.

Financial Disclosure: The authors declared that this study has received no financial support.

Finansal Destek: Yazarlar bu çalışma için finansal destek almadıklarını beyan etmişlerdir.

Geliş Tarihi / Received: 17.05.2021

Kabul Tarihi / Accepted: 01.07.2021

Yayın Tarihi / Published: 02.08.2021

Sorumlu yazar / Corresponding author:

Ender Kaya

Adres/Address: University of Health Sciences, Prof. Dr. Cemil Tascioglu City Hospital, Clinic of Psychiatry, Istanbul, Turkey.

e-mail: enderkaya76@yahoo.com

Tel/Phone: 02123145555

Fax: $\quad 02122217800$

Copyright $(\subset$ ACEM 


\section{Introduction}

Depression is a mental disorder which is commonly encountered and usually progresses with relapses. It is known that $29-46 \%$ of patients with depression partly or never respond to antidepressant treatment. Residual symptoms are observed not only in patients in partial remission, but also in patients meeting the remission criteria. Even if residual symptoms are mild, they lead to disability [1]. In addition, residual symptoms may increase the depression relapse risk by extending the depressive syndrome and aggravating the clinical picture [2]. The two most commonly encountered residual symptoms are cognitive and psychosocial dysfunctions in MDD in remission phase [3].

It has been reported that cognitive functional disorder in MDD can be healed with the treatment of depressive symptoms; however, residual cognitive symptoms might even be encountered in the remission period. In full or partial remission, residual cognitive symptoms might be seen at the level of $44 \%$ [4]. MDD patients in remission have residual cognitive symptoms in the areas of attention, memory, data processing speed and executive cognitive function $[5,6]$. In depression, the presence of cognitive impairment is an important factor affecting social and occupational functioning in illness and remission phases and affects the course of disease negatively [7].

Treatments in MDD make improvement in psychosocial functioning and quality of life. However, functional disorders often continue in depressive patients even if improvement is made in symptom severity [8]. Moreover, these patients cannot reach the functional levels of non-depressive individuals [9]. Also it is known that residual cognitive functional symptoms in MDD patients in remission phase may impair psychosocial functioning [10], which arises a curiosity about the correlation of residual cognitive symptoms of depression encountered in the remission phase with dysfunctions.

Neuropsychological tests are usually accepted as 'gold standard' in evaluating cognitive dysfunction. However, as neuropsychological evaluation requires a specific expertise and is hard to access for patients and clinicians, it is not practical for routine clinical practice [11]. Cognitive evaluation scales which are rated by the patient may provide a more detailed evaluation beyond the standard clinical evaluation of cognition. In addition it has been reported that subjective cognitive changes are strongly correlated with changes in neuropsychological tests [12]. Within this framework, the correlation of subjective cognitive changes with social functioning in major depressive patients has aroused curiosity. Our study can contribute to the elimination of the deficiency in the literature.

The aim of this study was to investigate the correlation of subjective residual depressive and cognitive symptoms with social functioning in MDD patients in remission. Also the study investigated the correlation between subjective residual cognitive symptoms, depressive symptoms and disease process. In accordance with this purpose, our primary hypothesis is that subjective residual cognitive and depressive symptoms in remitted MDD patients may affect social functioning negatively.

\section{Material and methods}

The study included 51 patients who were previously diagnosed with MDD in the psychiatry outpatient clinic and were followed up regularly (55 patients were invited to the study. 4 patients did not want to participate in the study). This study was conducted between November 2020 and March 2021. In the study the patients who were voluntary to take part in the study, were aged 18 to 65 years, were previously diagnosed with MDD and were remitted for at least 6 months, were included (BDI <17)
[13]. Presence of a neurological or general medical disease that might impair cognitive functions, mental retardation, psychotic disorder, bipolar disorder and psychoactive substance use/abuse were determined as exclusion criteria. The patients meeting the study criteria were given detailed information about the study. Informed consent form was received from the patients who agreed to take part in the study. Following the diagnostic interview (SCID-1) conducted with the patients, the sociodemographic information form, Perceived Deficits Questionnaire-Depression (PDQ-D), Social Adaptation Selfevaluation Scale (SASS), and Beck Depression Inventory (BDI) were applied to the patients.

The study was conducted in compliance with Good Clinical Practice requirements and the Declaration of Helsinki.

\section{Data Collection Tools}

Socio-demographic information form: Questions the demographic characteristics of patients (such as age, gender, number of depressive episodes (NDE), number of admissions to hospital with depression diagnosis (NHA), number of suicide attempts (NSA)).

Structured Clinical Interview for DSM-IV Axis I Disorders (SCID-I): Developed as a structured clinical diagnosis tool, the SCID-I enables investigating whether there was any axis I diagnosis in the past and/or it has been present within the past month or not according to the DSM diagnostic criteria via mutual interviews. SCID-I was developed by First et al., and its Turkish adaptation and reliability study was conducted by Özkürkçügil et al $[14,15]$.

Table 1. Socio-demographic and clinical characteristics and psychometric test scores of the patients.

\begin{tabular}{lcc} 
& Mean/Number & $\mathrm{Sd} / \%$ \\
\hline Gender (female) & 42 & 82 \\
Age (year) & 41.8 & 8.5 \\
NHA & 0.2 & 0.5 \\
NSA & 0.6 & 0.8 \\
NDE & 2.5 & 1.2 \\
BDI & 9.7 & 3.4 \\
SASS & 34.5 & 9.4 \\
PDQ-D & & \\
$\quad$ Attention/Concentration & 6.7 & 3.7 \\
$\quad$ Prospective Memory & 5.8 & 2.8 \\
$\quad$ Retrospective Memory & 6.7 & 4.0 \\
$\quad$ Planning/Organization & 5.8 & 2.5 \\
$\quad$ Total & 25.6 & 11.8 \\
\hline
\end{tabular}

NHA: Number of hospital admissions, NSA: Number of suicide attempts, NDE: Number of depressive episodes, BDI: Beck Depression Inventory, SASS: Social Adaptation Self-evaluation Scale, PDQ-D: Perceived Deficits QuestionnaireDepression.

Perceived Deficits Questionnaire-Depression (PDQD): The Perceived Deficits Questionnaire [16] is a self-report questionnaire which was initially developed to measure cognitive dysfunction as part of the Quality of Life Battery in multiple sclerosis patients [17]. The questionnaire has four subscales each of which comprises five items, making 20 items in total: attention/concentration, retrospective memory, prospective memory and planning/organization. Scoring is made according to the last four weeks. Each item is rated in a five-point scale: $0=$ never, 1 =seldomly, 2=sometimes, 3=frequently, 4=almost always. Total score ranges from 0 to 80 . Higher scores indicate 
that the perceived deficit is higher. The questionnaire has been made appropriate for use in Major Depressive Disorder patients. Scoring for the PDQ-Depression (PDQ-D) is made according to the last seven days and some questions have been altered in such a way to comprise patients with depression more [18]. Validity and reliability study of its Turkish version was conducted by Aydemir et al. in 2017 [19].

Social Adaptation Self-evaluation Scale (SASS): The scale was developed by Bosc et al. [20]. The Turkish validity and reliability study of the scale was conducted by Akkaya et al [21]. It is a 21-item self-evaluation scale developed to determine the 'social functioning' levels of patients with depression. As only one of the first and second items is completed according to the professional status, each person responds to 20 items which are rated in the range of $0-3$ in total. In the scale, which is evaluated in the range of 0-60 points, it is reported that the individual must get at least 35 points in order to have normal social functionality, and if he/she gets a score below 25 , there is a problem in social functioning.

Beck Depression Inventory (BDI): Measures physical, emotional and cognitive symptoms in depression. It is a selfassessment inventory containing 21 symptom categories. The highest score is 63 . Highness of the total score indicates the severity of depression [22]. Its Turkish validity and reliability study was conducted by Hisli and the limit value for the inventory was determined to be 17 [13].

\section{Statistical analysis}

In the assessment of the findings, the IBM SPSS Statistics 22 (IBM SPSS, Turkey) program for statistical analyses was used. When evaluating the study data, whether the parameters were normally distributed or not was evaluated via the Shapiro-Wilk test. As the parameters were normally distributed, the Pearson's correlation analysis was used in examining the correlation. The linear regression analysis was used in evaluating the effect of the BDI and PDQ-D total scores on SASS. The statistical significance value was accepted as $\mathrm{p}<0.05$.

\section{Results}

Table 1 shows the socio-demographic and clinical characteristics and psychometric test scores of the patients.

\section{Correlation Analysis}

It was determined that there was a positive significant correlation between BDI scores and PDQ-D total scores $(\mathrm{r}=0.360, \mathrm{p}<0.01)$. There was a significant correlation between BDI scores and the attention/concentration $(\mathrm{r}=0.459, \mathrm{p}<0.01)$, retrospective memory $(\mathrm{r}=0.335, \quad \mathrm{p}<0.05)$, and planning/organization $(\mathrm{r}=0.399, \mathrm{p}<0.05)$ subscales of PDQ-D. There was a negative significant correlation between BDI scores and SASS scores $(\mathrm{r}=-0.357, \mathrm{p}<0.05)$. A negative significant correlation was found between PDQ-D total scores and SASS scores $(r=-0.356, p<0.05)$. There was a positive significant correlation between PDQ-D total scores and number of depressive episodes (NDE) $(r=289, \mathrm{p}<0.05)$.

Table 2: Correlations between BDI, PDQ-D and SASS and points of remitted MDD patients with disease characteristics.

\begin{tabular}{|c|c|c|c|c|c|c|c|c|c|c|c|}
\hline & & 1 & 2 & 3 & 4 & 5 & 6 & 7 & 8 & 9 & 10 \\
\hline \multirow[t]{2}{*}{ 1.BDI } & $r$ & 1 & & & & & & & & & \\
\hline & $p$ & & & & & & & & & & \\
\hline \multirow{2}{*}{$\begin{array}{l}\text { 2.Attention/ } \\
\text { Concentration }\end{array}$} & $r$ & $0.459 * *$ & 1 & & & & & & & & \\
\hline & $p$ & 0.001 & & & & & & & & & \\
\hline \multirow{2}{*}{$\begin{array}{l}\text { 3.Prospective } \\
\text { Memory }\end{array}$} & $r$ & 0.145 & 0.277 & 1 & & & & & & & \\
\hline & $p$ & 0.311 & 0.049 & & & & & & & & \\
\hline \multirow{2}{*}{$\begin{array}{l}\text { 4. Retrospective } \\
\text { Memory }\end{array}$} & $r$ & $0.335^{*}$ & $0.819 * *$ & $0.543^{* *}$ & 1 & & & & & & \\
\hline & $p$ & 0.016 & 0.000 & 0.000 & & & & & & & \\
\hline \multirow{2}{*}{$\begin{array}{l}\text { 5.Planning/ } \\
\text { Organization }\end{array}$} & $r$ & $0.399 * *$ & $0.624 * *$ & $0.608 * *$ & $0.586 * *$ & 1 & & & & & \\
\hline & $p$ & 0.004 & 0.000 & 0.000 & 0.000 & & & & & & \\
\hline \multirow[t]{2}{*}{ 6. PDQ-D Total } & $r$ & $0.360 * *$ & $0.794^{* *}$ & $0.726^{* *}$ & $0.891^{* *}$ & 0.782 & 1 & & & & \\
\hline & $p$ & 0.009 & 0.000 & 0.000 & 0.000 & 0.000 & & & & & \\
\hline \multirow{3}{*}{ 7. SASS } & $r$ & $-0.357^{*}$ & -0.044 & $-0.528^{* *}$ & -0.168 & $-0.432 * *$ & $-0.356^{*}$ & 1 & & & \\
\hline & $p$ & 0.010 & 0.761 & 0.000 & 0.239 & 0.000 & 0.010 & & & & \\
\hline & $r$ & $0.358^{* *}$ & 0.021 & $0.376 * *$ & 0.234 & 0.259 & $0.289 *$ & $-0.531 * *$ & 1 & & \\
\hline \multirow[t]{2}{*}{ 8. NDE } & $p$ & 0.010 & 0.885 & 0.006 & 0.098 & 0.066 & 0.040 & 0.000 & & & \\
\hline & $r$ & -0.162 & -0.223 & 0.038 & -0.089 & 0.153 & -0.035 & -0.163 & 0.238 & 1 & \\
\hline \multirow[t]{2}{*}{ 9. NHA } & $p$ & 0.257 & 0.116 & 0.792 & 0.535 & 0.283 & 0.807 & 0.254 & 0.092 & & \\
\hline & $r$ & -0.057 & -0.188 & $0.536 * *$ & 0.144 & 0.134 & 0.220 & $-0.495^{* *}$ & $0.360^{* *}$ & $0.376^{* *}$ & 1 \\
\hline 10. NSA & $p$ & 0.689 & 0.186 & 0.000 & 0.315 & 0.347 & 0.120 & 0.000 & 0.009 & 0.007 & \\
\hline
\end{tabular}

* Statistical significance was defined as $\mathrm{p}<0.05, * * \mathrm{P} \leq 0.01$. BDI: Beck Depression Inventory, PDQ-D: Perceived Deficits Questionnaire-Depression, SASS: Social Adaptation Self-evaluation Scale, NDE: Number of depressive episodes, NHA: Number of hospital admissions, NSA: Number of suicide attempts. 
A negative significant correlation was determined between SASS scores and prospective memory $(\mathrm{r}=-0.528, \mathrm{p}<0.01)$, planning/organization $(\mathrm{r}=-0.432, \mathrm{p}<0.01)$ and number of suicide attempts $(\mathrm{r}=-495, \mathrm{p}<0.01)$ (Table 2$)$.

\section{Regression Analysis}

While SASS was used as dependent variable, BDI and PDQ-D total scores were assigned as independent variable. The linear regression analysis results indicated that BDI $(\mathrm{R} 2=0.128)$ and PDQ-D total $(\mathrm{R} 2=0.127)$ scores were a predictor of SASS $(\mathrm{p}<0.05)($ Table 3$)$.

Table 3. Linear regression analysis results for variables predicting SASS total points.

Dependent Predictors B Std E Beta $\quad$ T $\quad p$

Variable

\begin{tabular}{llllccc}
\hline SASS & BDI & -0.993 & 0.371 & - & - & 0.01 \\
& & & & 0.357 & 2.679 & \\
& PDQ-D & -0.283 & 0.106 & - & - & 0.01 \\
& Total & & & 0.356 & 2.668 & \\
\hline
\end{tabular}

Statistical significance was defined as $\mathrm{p}<0.05$, BDI: Beck Depression Inventory, SASS: Social Adaptation Self-evaluation Scale, PDQ-D: Perceived Deficits Questionnaire-Depression.

\section{Discussion}

The study investigated the correlation of residual depressive and subjective cognitive symptoms with social functioning in remitted MDD patients. In the present study, it was determined that there was a significant correlation between subjective cognitive and depressive symptoms and social functioning.

In the present study it was found that there was a significant correlation between the number of past episodes and subjective cognitive impairment in MDD patients in remission phase. Similarly there are studies emphasizing the correlation between the number of depressive episodes and cognitive impairment in patients with depression in remission phase [23]. On the other hand, there are studies finding no evidence to this correlation at all $[24,25]$.

In the present study it was determined that there was a significant correlation between residual depressive symptoms and residual subjective cognitive symptoms and social dysfunction. In addition, residual depressive symptoms were a predictor of social dysfunction. Residual depressive symptoms may impair psychosocial functioning [26]. However, residual depressive symptoms alone do not explain the social dysfunction. Moreover it has been reported that as long as residual depressive impact is controlled, cognitive symptoms play a key role in functional improvement [7].

In the present study it was determined that there was a significant correlation between residual subjective cognitive symptoms and social dysfunction. Also residual subjective cognitive symptoms were a predictor of social dysfunction. $60 \%$ of MDD patients have neurocognitive deficits six months after the treatment [7]. In previous studies, it was reported that residual cognitive symptoms might be encountered in MDD patients in remission [27] and these symptoms might play a role in social dysfunction [5]. In addition, Nierenberg et al., suggested that residual symptoms in the remission phase might be associated with impairment in psychosocial functioning in $80 \%$ of cases [28]. The presence of these residual symptoms may increase dysfunction and destroy the quality of life of patients [4]. As a consequence, psychotherapeutic interventions aiming to heal residual cognitive symptoms in the remission period, may contribute to the improvement of social functioning.
In the present study, it was determined that there was a negative significant correlation between the prospective memory and planning/organization subscales of PDQ-D and social dysfunction. In the remission phase of major depression, impairment is observed in attention, memory and executive functions [10, 29]. Decrease in the speed of mental processes associated with cognitive functions may restrict the daily life functions of patients and reduce their interaction with other people. Thus, social functioning of patients may be affected negatively.

Cognitive tests are used in identifying the depression risk in the early period. By this way, evaluating cognitive symptoms in individuals under risk, following the changes in these symptoms and initiating appropriate treatment interventions in the early period may contribute to the course of disease positively [30]. In the evaluation process of these patients, rapid and practical subjective cognitive tests can be preferred as an alternative to objective neurocognitive batteries.

The present study had some limitations. First of all, as the study was cross-sectional, it was hard to make an inference about the cause and effect relationship. Secondly the depression patients who suffered from depression with psychotic characteristics in the past could not be distinguished. The third limitation was the small number of cases. Finally the patients took psychotropic drugs (antidepressants, antipsychotics, benzodiazepines, mood stabilizers). As it would not be ethical to terminate the medications causing residual cognitive symptoms, the study was conducted with the patients who were under medication.

As a consequence, residual depressive and subjective cognitive symptoms are associated with social dysfunction in remitted MDD patients. Residual depressive and subjective cognitive symptoms in these patients may be a determinant of social functioning. Thus it is crucial to identify cognitive symptoms early and intervene in these symptoms in order to enhance social functioning in the remission phase in MDD. Also rapid and practical subjective cognitive scales in clinics can be used as an alternative to neuropsychological tests in evaluating cognitive changes.

\section{References}

1. Fava M, Davidson KG. Definition and epidemiology of treatment resistant depression. Psychiatr Clin North Am. 1996;19:179-195.

2. Ramana R, Paykel ES, Cooper Z, Hayhurst H, Saxty M, Surtees PG. Remission and relapse in major depression: a two-year prospective follow-up study. Psychol Med. 1995;25:1161-70.

3. Fava M, Graves LM, Benazzi F, Scalia MJ, Iosifescu DV, Alpert JE, Papakostas GI. A cross-sectional study of the prevalence of cognitive and physical symptoms during long-term antidepressant treatment. J Clin Psychiatry. 2006;67:1754-9.

4. Conradi HJ, Ormel J, de Jonge P. Presence of individual (residual) symptoms during depressive episodes and periods of remission: a 3-year prospective study. Psychol Med. 2011;41:116574.

5. Baune BT, Miller R, McAfoose J, Johnson M, Quirk F, Mitchell D. The role of cognitive impairment in general functioning in major depression. Psychiatry Res. 2010;176:183-9.

6. Halvorsen M, Høifødt RS, Myrbakk IN, Wang CE, Sundet K, Eisemann M, Waterloo K. Cognitive function in unipolar major depression: a comparison of currently depressed, previously depressed, and never depressed individuals. J Clin Exp Neuropsychol. 2012;34:782-90.

7. Jaeger J, Berns S, Uzelac S, Davis CS. Neurocognitive deficits and disability in major depressive disorder. Psychiatry Res. 2006; 145:39-48.

8. Hirschfeld RM, Dunner DL, Keitner G, Klein DN, Koran LM, Kornstein SG, et al. Does psychosocial functioning improve 
independent of depressive symptoms? A comparison of nefazodone, psychotherapy, and their combination. Biol Psychiatry. 2002;51:123-33.

9. Miller IW, Keitner GI, Schatzberg AF.The treatment of chronic depression, pt 3: psychosocial functioning before and after treatment with sertraline or imipramine. J Clin Psychiatry. 1998;59:608-19.

10. Hasselbalch BJ, Knorr U, Kessing LV. Cognitive impairment in the remitted state of unipolar depressive disorder: a systematic review. J Affect Disord. 2011;134:20-31.

11. Cha D. Cognitive Impairment in Major Depressive Disorder: Clinical Relevance, Biological Substrates, and Treatment Opportunities (R. McIntyre, Ed.). Cambridge: Cambridge University Press. 2016; doi: 10.1017/CBO9781139860567.

12. Zimprich D, Martin M, Kliegel M. Subjective Cognitive Complaints, Memory Performance, and Depressive Affect In Old Age: A Change-Oriented Approach. Int J Aging Hum Dev. 2003;57:339-66.

13. Hisli N. Beck Depresyon Envanterinin üniversite öğrencileri için geçerliği, güvenirliği. Psikoloji Dergisi. 1989;7:3-13.

14. First MB, Spitzer RL, Gibbon M, Williams JBW. Structured clinical interview for DSM-IV axis I disorders, clinician version (SCID-CV). Washington, DC: American Psychiatric Press; 1996.

15. Özkürkçügil A, Aydemir Ö, Yıldız M, Danacı AE, Köroğlu E. DSM-IV Eksen I bozuklukları için Yapılandırılmış Klinik Görüşmenin Türkçe'ye uyarlanması ve güvenilirlik çalışması. İlaç ve Tedavi Derg. 1999;12:233-36.

16. Sullivan MJL, Edgley K, Dehoux E. A survey of multiple sclerosis. Part 1: Perceived cognitive problems and compensatory strategy use. Canadian Journal of Rehabilitation. 1990;4: 99-105.

17. Fischer JS, LaRocca NG, Miller DM, Ritvo PG, Andrews H, Paty D. Recent developments in the assessment of quality of life in multiple sclerosis (MS). Mult Scler. 1999;5:251-59.

18. Fehnel SE, Forsyth BH, DiBenedetti DB, Danchenko N, François $\mathrm{C}$, Brevig T. Patient-centered assessment of cognitive symptoms of depression. CNS Spectr. 2016;21:43-52.

19. Aydemir O, Cokmus FP, Akdeniz, Suculluoglu-Dikici D, Balikci K. Psychometric properties of the Turkish Versions of Perceived Deficit Questionnaire - Depression and British Columbia Cognitive Complaints Inventory. Anatolian Journal of Psychiatry. 2017;18:224-30.

20. Bosc M, Dubini A, Polin V. Development and validation of a social functioning scale, the Social Adaptation Self- evaluation scale. Eur Neuropsychopharmacol. 1997;7: 57 -70.

21. Akkaya C, Sarandöl A, Esen Danacı A, Sivrioğlu Y, Kaya E, Kırlı S. Sosyal Uyum Kendini Değerlendirme Ölçeği (SUKDÖ) Türkçe Formunun Geçerlik ve Güvenilirliği Türk Psikiyatri Dergisi. 2008;19: 292-99.

22. Beck AT. An inventory for measuring depression. Arch Gen Psychiatry. 1961;4:561-71.

23. Sumiyoshi T, Watanabe K, Noto S, Sakamoto S, Moriguchi Y, Hammer-Helmich L, Fernandez J. Relationship of Subjective Cognitive Impairment with Psychosocial Function and Relapse of Depressive Symptoms in Patients with Major Depressive Disorder: Analysis of Longitudinal Data from PERFORM-J. Neuropsychiatr Dis Treat. 2021; 26:17:945-955.

24. Behnken A, Schoning S, Gerss J, Konrad C, de Jong-Meyer R, Zwanzger $\mathrm{P}$, et al. Persistent non-verbal memory impairment in remitted major depression - caused by encoding deficits? J Affect Disord 2010;122:144-8.

25. Biringer E, Arvid R, Anders L. A review of modern antidepressants' effects on neurocognitive function. Curr Psychiatry Rev. 2009; 5:164-74.

26. Sadek N, Bona J. Subsendromal symptomatic depression: A new concept. Depress Anxiety. 2000;12:30-9.

27. Roiser JP, Sahakian BJ. Hot and cold cognition in depression. CNS Spectr. 2013; 18(3):139-49.

28. Nierenberg AA, Keefe BR, Leslie VC, Alpert JE, Pava JA, Worthington JJ, 3rd, et al. Residual symptoms in depressed patients who respond acutely to fluoxetine. J Clin Psychiatry. 1999;60:2215 .

29. Rock PL, Roiser JP, Riedel WJ, Blackwell AD. Cognitive impairment in depression: a systematic review and meta-analysis. Psychol Med. 2014;44: 2029-40.

30. Robinson OJ, Sahakian BJ. Cognitive biomarkers in depression. In H. Lavretsky, M. Sajatovic, \& C. F. Reynolds III (Eds.), Late-life mood disorders. Oxford University Press. 2013;606-26. 